\title{
Grief and Stress Communication and Management in Euripides' Iphigenia in Aulis
}

\author{
Chandima S. M. Wickramasinghe \\ Dept. of Classical Languages, Faculty of Arts, University of Peradeniya, Sri Lanka
}

\begin{abstract}
Communication, an essential human trait, is vital to develop a great connectedness among individuals as it helps to understand human mind and emotions. Grief and stress are communicated in different proportions in ancient Greek tragedies, which revolve around a plot that emanates grief. The characters in a Greek tragedy are affected by or are victims of a grieving situation central to the play. Aristotle maintained that tragic action must emanate pity and fear which are connected with grief and stress. Euripides, the revolutionary dramatist of Classical Athens, has empowered his characters to the effect of transmitting their sentiments freely. This feature is notable in his plays such as Alcestis, Electra, Ion, Orestes and Iphigenia in Aulis (IA). In IA, a well-established mythical account is presented as a simple family story. It is not just Iphigenia, who is affected by her impending tragedy. Almost all characters grieve in different proportions, while attempting to manage their grief and stress first by communicating it and then in ways peculiar to themselves. The strategies range from keeping a positive attitude, accepting the situations, to being assertive instead of being aggressive. This study examines the communication of grief and stress as a means of managing such sentiments with especial reference to Iphigenia in Aulis in order to understand how Euripidean tragedy could bring relief to its audience. In the process, the study observes how the dynamics of engagement of a character with others, their feelings, thoughts and intentions can contribute to manage grief and stress through effective communication of such sentiments.
\end{abstract}

Keywords: grief and stress, communication, management, Euripides, Iphigenia in Aulis

\section{Introduction and scope}

Emotions such as grief and stress are passive impacts on an individual's mind in response to a situation lined with some loss (MacCandless, 1978, p.26. Also, Sim et al, 2014, pp. 1211-1212). Human mind is naturally variable ${ }^{1}$ and its activities such as feeling of emotions may pass unnoticed. Yet, the emotions are hard to delineate (Allard, et al, 2018, p. 24) as they tend to change based on situations and individual experiences. Such passive demeanour of the mind can be empowered and articulated by means of poetic techne which incorporates language and expression. Here, we recollect, W. Arrowsmith's view (1963, pp. 32-56), that the stage was the medium of thought for a dramatist and his entire machination was to use theatre as a manifestation of constructive and critical thoughts about his world.

Ancient Greek tragedies ${ }^{2}$ were imitations of action (Daniels and Scully, 1992, pp. 206-207), which includes a series of events. Greek tragedians ${ }^{3}$ configured their plots (which could be either simple or complex) based on

\footnotetext{
${ }^{1}$ As opposed to the possible invariability of an individual's character.

2 These were theatrical performances in ancient Greece and flourished during the fifth century BC (Classical period) in Athens and were also known as Attic tragedy. The themes of these plays dealt with human miseries and their plots were derived from popular Greek myths or legends.
}

3 The most known and leading Greek tragedians were Athenians namely, Aeschylus, Sophocles and Euripides who were contemporaries at one time. Of these, the two former dramatists were idealists, who respected old order

\footnotetext{
${ }^{*}$ Corresponding author: Chandima S. M. Wickramasinghe, Dept. of Classical Languages, Faculty of Arts, University of Peradeniya, Sri Lanka; csmwickramasinghe16@gmail.com

(c) TIIKM Publishing
} 
well-established popular mythical accounts. The dramatists generally customized the chosen myth to suit their desired objectives by incorporating certain twists and turns to the detail of the myth. Accordingly, the Greek tragedians could present tragic plots containing make-believe actions and make-believe responses (construed from myth) aptly fused with real-life actions and responses to provide instructions on contemporary issues (Also see Daniels and Scully, 1992, p.206). Such hybridity would enable the audience to better understand a scene and feel the emotions proper to that scene sometimes with the aid of the chorus who would facilitate the audiences (representatives of the community) to assess which of the characters deserve compassion (Woodruff, 2016, p. 149). Yet, since all individuals affected by emotional pain, suffering and grief are not ready to communicate or share such sentiments with others, for the fear of rejection or of being talked weak (MacCandless, 1978, p. 20), Greek tragedians may have tried to provoke the contemporary Greeks to communicate their emotions through their plays as a therapeutic alternative.

Nonetheless, it must be noted that the cultural process and the theatrical paraphernalia of Classical Athenian tragic theatre focus more on verbal communication of ideas and sentiments than expressing them through visual expression or action. However, in some other occasions a close analysis of both the speech and action of a character may, at least, hint at the impact of mental disturbances caused by grief and stress on that particular character. Here, one must note that since the ancient Greek tragedies revolve around a plot that emanates grief and distress (prolonged stress), the characters in a Greek tragedy are affected by or are victims of a grieving situation central to the play. Even Aristotle (in Poetics and Rhetorics) has recognized that the tragic action must emit pity and fear, which contain strong cognitive and psychological elements (Also cf. Briassoulis, 2019, p. 10951096; Woodruff, 2016, pp. 146-149: cognitive faculties of pity and fear; Cavarnos, 1979, p. 57 and Konstan, 1999, pp. 1-2: definitions of pity and fear in Rhetorics). Naturally, such sentiments may either result from or may cause grief and stress, communicated in tragedies, in different proportions. Responding to another's emotions or understanding another's emotions may also occur as a result of reading the mind of an individual and such an ability involves cognition, a key human skill (Budelmann and Easterling, 2010, p. 291. Also, Woodruff, 2016, pp. 146-147).

When communicated, negative emotions may not only attract social attention to individuals' sentiments but also may provide support to those affected by them to manage, if not to alleviate, the same sentiments. Such an endeavour is vital for much of the human experiences and for 'our natural way of understanding social environment' (Dunbar, 2000, p. 242; Baron-Cohen, 1995, note 4, p. 4, taken from Budelmann and Easterling, 2010, note 5, p. 291). Negotiations and values are basic social processes vital for social interaction (Hall, 1990, p.8) and, compromises occur when the values are negotiable (Hall, 1990, p.14). Such views are based on concepts such as human beings have no existence in isolation and, that interactions with others is an essential human trait. Similarly, we must remember that connectedness is not self-enhancing at all times but, it could also be destructive at certain occasions (MacCandless, 1978, p.22). Interdependency arises from the connectedness between people, a necessary aspect of human identity (Hall, 1990, pp. 14-15). Usually, bonds and interdependencies improve when individuals concerned share [or are affected by] negative sentiments. Accordingly, plots of ancient Greek tragedies, being imitations of human actions, are sure to manifest and sustain bonds and interactions between individuals by means of communicating negative sentiments such as grief and stress.

Here, our attention is on Euripides, the revolutionary dramatist, who surpassed socio-cultural conventions as he inserted innovations and a sense of modernity into his plays. Most Euripidean characters are portrayed with less control over their actions being victims of their emotions, but not hostages of their fate. Numerous studies were conducted on various aspects of ancient Greek tragedies and on Euripidean theatre. Among these, J-N. Allard et al (2018) "Gendered construction of emotions in the Greek and Roman world", D. Bacalexi's (2018) "Personal,

and tradition, though Euripides was known as the revolutionist for representing the new order and for surpassing the convention perhaps in his attempt to represent reality and for his innovative dramatic performances. 
paternal, patriotic: the threefold sacrifice of Iphigenia in Euripides' Iphigenia in Aulis", P. Woodruff's (2016) "Sharing emotions through theatre: the Greek way", F. Bundelmann and P. Easterling's (2010) "Reading minds in Greek tragedy", J. H. Kim On Chong-Gossard's (2003) 'Song and the solitary self: Euripidean women who resist comfort', J.J. Chapman's (1993) "Euripides and Greek genius”, D. J. Conacher's, (1981) 'Rhetoric and relevance in Euripidean drama', J. Ferguson's (1968) "Iphigenia at Aulis" and W. Arrowsmith's (1963) "A Greek theatre of ideas" are noteworthy. Furthermore, the studies of H. Briassoulis (2019) 'The Catharsis of the commons', T. Tielemann, (2019) 'Wisdom and emotion: Galen's philosophical position in avoiding distress', T. Gamliel, (2014) 'Therapeutic aspects of "Traditional” wailing performance', R. Dunbar, (2000) 'On the origins of the human mind' also deserves attention for their scholarly contribution for the present study.

However, no study has explored how negative emotions as grief and stress can be managed, if not alleviated, by communicating such sentiments in Euripidean plays. The present study, therefore, intends to explore how grief and stress can be managed with special reference to Iphigenia in Aulis (IA). In the process it also focuses on how the dynamics of engagement of a character with others, their feelings, thoughts and intentions can contribute as an initial step or strategy to manage grief and stress. The study is also an attempt to present a new outlook of cathartic function effected by Euripidean plays. Given the nature of this study it follows a qualitative research based on literary sources. As for the primary literary sources the study pays attention to the play of our concern and related plays in their original language - ancient Greek - as well as in translations. All relevant secondary sources are explored with a critical and analytical approach in the course of presenting the arguments in the discussion to fulfil the objectives.

\section{Communication as a strategy to manage grief and stress}

The central crisis of Euripides' Iphigenia in Aulis is the imminent sacrifice of Iphigenia, the young daughter of Agamemnon and Clytemnestra, to the goddess Artemis (See Kim, 2003, p.213: Artemis power over life and death of women). The core of the myth upon which Euripides based his plot was that Iphigenia was to sacrifice to Artemis to enable Greeks to receive fair winds to sail to Troy. ${ }^{4}$ Iphigenia was lured to Aulis and was sacrificed, but was saved by Artemis at the moment of sacrifice. Euripides customized this myth adding few amendments such as, Agamemnon's attempt to change his first message to Clytemnestra; Iphigenia being chaperoned by Clytemnestra to Aulis; slave's betrayal of Agamemnon's scheme; Achilles' offer of help to save Iphigenia; Iphigenia volunteering to offer her life, and Iphigenia's miraculous salvage from death.

All main characters in the play from Agamemnon to Achilles grieve in varying degrees of intensity based on the way each were connected and affected by the crisis, while the chorus of Calchian female visitors and the old slave tried to share the grief or to empathize with those affected. It is the connectedness among humans that has come to surface in the manner of communicating their grief and stress from the very outset of the play. Notably, the characters seek to possess and maintain meaningful identity by acknowledging their emotional relatedness to others.

\section{Agamemnon}

The play begins with Agamemnon's restless and sleepless behaviour in the night in his tent, the symbol of his private sphere, away from the military or professional engagements, as he regrets his former decision to offer his child to Artemis. Male slave complied with Agamemnon's orders and tried to conciliate him by assisting him to prevent the sacrifice. Agamemnon's grief reactions such as fatigue, anger, anxiety and guilt, are clearly communicated through the conversation with this slave. Agamemnon's emotional and physical reactions to pending physical, social and occupational losses are interconnected through his socio-political position (Ferguson,

\footnotetext{
${ }^{4}$ To punish Paris, (the son of the Trojan king Priam) for abducting Hellen, the wife of Menelaus.
} 
1968, p. 159. Also see MacCandless, 1978, pp. 20-22). The imminent death of his child he himself engineered shall incur the physical loss (death of his family members), the social loss (i.e., loss of love and respect he so far enjoyed in his family) and the professional loss (i.e., the loss of his stature in the Greek army as its leader and/or his position as the king of Argos) may occur, as Agamemnon himself anticipates, irrespective of his acceptance or denial to offer his child (IA lines 528-536 and 1267-1268). Moreover, Agamemnon's long monologue (lines 49-115) $)^{5}$ reminds him, while communicating to others, that his initial decision was influenced by Calchas, Odysseus and Menelaus (IA lines 106-107), to whom he attributes the guilt. His calculated speech reveals his initial action against sacrificing the child (IA lines 85-105). His grief and distress are explicit as he conveys his repentance over the wrong decision taken and his resolve to correct it: 'I made a wrong decision then; Now I am reversing it' (IA lines107-108). Agamemnon's anxiety over the potentiality of delivering the second message and its success (IA lines 118-163) is a further indication of the intense agony he felt through his own scheme of action (See Zuntz, 1955, pp. 12-13 for a parallel suffering incurred by Adrastus in Suppliant women).

Here, one may remember that grief and stress are value laden sentiments and that their intensity is determined by the value one attaches to a loss. The inner values connected with Agamemnon's private life has rendered him guilt consciousness for contriving to bring death upon his child, whose life valued much to him, and that has provoked him to avert that loss (at least when he was momentarily influenced by family bonds). But Menelaus' accusation on Agamemnon of not possessing a static mind apt for a general (as he changed his decision to sacrifice the child), testifies how the professional or occupational instincts linked with external values provoked him to offer his child (IA lines 334-372). As the king of Argos and the Commander of the Greek army at Aulis, Agamemnon's responsibilities supersede those for his family. His accountability for the safety of entire Greece, of Argos, and that of the people may urge Agamemnon to put his country and people before his child. ${ }^{6}$ Greek tragedies being theatrical illustrations of how to live with members of the polis (Zuntz, 1955, p. 6) may have favoured such politically oriented demeanour in statesmen and Euripides may have used this play as a political propaganda. Such could have been the mental disposition Euripides expected to instil in Athenian military personals when Athens was at war with Sparta and her allies (Peloponnesian War) ${ }^{7}$. But Agamemnon shows his grief coated guilt consciousness at times perhaps when he is disturbed by his familial obligations. For instance, Agamemnon is very nervous as the messenger informed him of the arrival of Iphigenia unexpectedly accompanied by her mother, his wife. Part of his grief, as stated above, could have been affected by the potential social loss, if his scheme to sacrifice Iphigenia is revealed to his wife (IA lines 441-464). Menelaus too was convinced later and wants to save Iphigenia, and urges Agamemnon to do the same (IA lines 473-500), even the chorus (of foreign female-travellers) praises Menelaus for his decision to spare the child's life (Hall, 1990, pp.31, 90). Yet, Agamemnon decides to proceed with this sacrifice, i.e., to accept one physical loss, to prevent multiple loses (i.e., to prevent the ruin of himself and the rest of his family members, his kingdom (Argos) and his position in the army: IA lines 503-542). Accordingly, though Agamemnon seemed settled with the decision to sacrifice Iphigenia because of the politicomilitary attachment influencing his thoughts, values and also his emotional response to loss, he nonetheless

\footnotetext{
${ }^{5}$ It refers to the mythical account embedded with the measure he claimed to have taken to avoid the murder of his child and how Menelaus compelled him to summon the child when Calchas' prophecy demanded the sacrifice of Iphigenia to Artemis in return of fair winds.

${ }^{6}$ Livy's remark on Roman men that their emotions were regulated by the national demand to protect the city (as noted in Allard et al, 2018, p.36) could also be true with regard to ancient Greek statesmen like Agamemnon.

${ }^{7}$ Euripides wrote this pay somewhere between 408 (after compiling Orestes) and 406, the year he died. The Peloponnesian War ended in 404 BC. Two battles were fought in 406 at Arginusae and in 405 at Aegospotami making Athenians and Spartans victorious respectively.
} 
succumbs to his inner feelings time to time venting deep agony (IA lines 655, 678-690, 747-748,1142-1143,15441547). ${ }^{8}$

Moreover, he finds a pacifier for his grief by attributing the cause of action to fate, the most domineering phenomenon he could think of besides gods: 'We are in Fate's grip, we are forced to go on; we must shed daughter's blood' (IA lines 508-509). Accordingly, the complexity of human mind exhibited through Agamemnon's character has arisen due to the complexity of the issue at hand. The intertwined nature of the losses he anticipated infers that Agamemnon is doomed to experience one or more loss regardless of his attempts to evade them. His emotional reactions to pending losses are clearly communicated not only in words but also in the action of weeping: 'I am ashamed to weep; and equally I am ashamed not to weep, in such a depth of grief' (IA lines 449-450, lines 1546-1449: where he weeps). His desire to communicate and share his grief and stress with others has permitted him a chance to regulate his negative sentiments.

Here, we recollect Galen's reference to freeing oneself from pain and loss or distress by means of freeing one from affection. In this context, two exceptional situations or misfortunes that do not allow one freeing from distress and grief are destruction of a homeland and punishment to a friend (Tielmann, 2019, pp.211-212). When analyzing Agamemnon's position in the view of Galen, the misfortunes of Agamemnon can be paired with the exceptional situations noted above. By argument the death contrived against one's child can be considered as a punishment caused to a friend according to L. Thomas' reading of the Greek term philos, (commonly translated into English as 'friend') which encapsulates a range of individuals from family members to shop keepers that we come across in the course of our lives (Thomas, 1987, pp. 217-218). This inevitable distress pinned on Agamemnon is clear even from another argument based on the view that one's best friend is one's own self. In this view, the deity used Iphigenia to punish Agamemnon. ${ }^{9}$ Thus, the imminent death of Iphigenia has incurred an inescapable distress upon Agamemnon.

The second unfreeable distress that appeared to have affected Agamemnon is connected with the postulated refusal to sacrifice Iphigenia. On one hand, such refusal may cause the imminent destruction of his kingdom, Argos, (as is made explicit through Agamemnon's anticipation of ruinous demeanour of war-loving Greek warriors if provoked by Odysseus). On the other hand, the prolonged absence of the leaders and warriors from their cities may attract foreign invasions risking their freedom. Accordingly, the distress and grief are sure to accompany Agamemnon whether he agrees or not to sacrifice his daughter. All these sentiments are clearly communicated in the play through monologues and dialogues.

\section{Achilles}

Achilles too reacts with grief and stress to situations that affect him. He first reacts emotionally to the occupational loss that has affected him, when he hears of the way the leaders have ill-used his name and neglected his position

${ }^{8}$ An analysis of Agamemnon's behaviour in the play match the five stage models of grief explained by E. KüblerRoss (in Goldstein, 2018, p.144) namely, denial, anger, bargaining, depression and acceptance. Accordingly, Agamemnon's attempt to avert the sacrifice of his daughter can be seen as the denial of sacrifice and his own decision to support it. He vents his anger at Menelaus' interception preventing his attempt to protect the child. It looks as if Agamemnon was bargaining with his own values. He is depressed as he realized the inevitability of the sacrifice which finally leads him to accept the challenge of sacrificing the child. However, we must understand that some of the stages overlap, for instance Agamemnon's grief and depression is evident till the last minute.

${ }^{9}$ In fact, according to some versions of the myth, Agamemnon has offended Artemis by killing a dear sacred to her and wanted to punish him by compelling him to sacrifice his child, Iphigenia, in her name: Apollodorus VI, Epitom II.10 \& III. 21. 
in the army. Soon, he too begins to feel the imminent physical loss of the girl proposed to him in marriage as a pretext to lure her to death (IA lines 920-975). All in all, a close look at the characters of Agamemnon and Achilles indicates that their grieving situations have resulted from their immoderate attachment to esteem, reputation and political power in par with Galen's remark about the cause of human grief (Tileman, 2019, p.212).

\section{Clytemnestra}

In addition to male characters, Clytemnestra and her daughter Iphigenia, the two key female characters in the play, are also inevitably affected by the potential physical loss i.e., the death of Iphigenia. The disparity of male female spheres, social demands and patriarchal societies become evident when examining the strategies used by female characters to communicate grief and stress in response to a respective loss that affected them. The distress and pain Clytemnestra experiences due to the looming physical loss aggravate as she realizes that it is connected with the potential social loss since her husband was the agent of such atrocious scheme. Thus, both her household and the family front, the crucial social sphere for a married woman, is at stake exposing her to double loss. Shock and disbelief were her initial responses to loss which then turned out to be despair and grief:

Old slave: "Iphigenia, her father, with his own hand, means to murder her."

Clytemnestra: "What? Oh, what a filthy thing to say! You must be raving mad."

Old slave: "With his sward he'll cut through her white throat, poor miserable child!"

Clytemnestra: "Oh, what shall I do? Can it then be my husband who is mad?"

Old slave: "Yes, he's mad, towards you and your daughter; otherwise, he's sane enough."

Clytemnestra: "What's his reason for it? What destroying Fury drives him on?"

Old slave: "Some god's bidding, so says Calchas, so that the Greek fleet can sail."

Clytemnestra: "Sail where? Oh, heaven help me, and help the child her father wants to kill!" (IA lines 873-880).

Her inquisitive nature, a typical characteristic of Euripidean women, helps her to delve further into the matter for detail (IA lines 876-899). Clytemnestra supplicates Achilles, her last resort to prevent her child being sacrificed (IA line 900-917). The supplication to Achilles and Clytemnestra's willingness to be his accomplice can be interpreted as a communication of her agitation, anxiety and haplessness at the verge of the potential physical loss. It also can be perceived as her acknowledgement of emotional relatedness to Iphigenia, and also to Achilles as the sole agent capable of averting the imminent physical loss. Here, she not only displays the sense of belonging she feels towards Iphigenia but also the need to have bonds with men. She is seeking to develop a bond (with Achilles) while renouncing another (with Agamemnon) towards sharing a 'common destiny' with Iphigenia. ${ }^{10}$ The exchange of ideas which initiated such a bond has characterized Clytemnestra's position and dimension of self and has led to develop a new potential to save Iphigenia which inevitably brings her some relief from mental agony (Also see Hall 1990, p. 15).

${ }^{10}$ The implicit idea of lines 918-919 in Iphigenia in Aulis could be that, 'for a mother, witnessing a child's death is more painful than facing her own death'. Also refer to IA lines 1210, 1211 on the remarks of the chorus of the value of saving a child's life. 
What is evident is that Clytemnestra disdains from being a conventional wife, a non-assertive, passive and a modest woman nodding placidly to her husband's authority (Also see Pritchard, 2014, p.182), ${ }^{11}$ at the brink of disaster to a child. Her present disposition as the accomplice of Achilles, fighting against her own husband, is highlighted when she refers to her conduct so far as the virtuous and chaste wife of Agamemnon even when she was subject to distress through his atrocious crimes that ruined her former marriage (IA lines 1143-1209). She was the conventional wife, who chose family-living consciously and deliberately having come to terms with life chances and herself, instead of looking for the perfect spouse (Hall, 1990, p. 22). The reference to Agamemnon's exercise of violence against Clytemnestra's former husband and child not only tarnishes the image of Agamemnon but, is also a careful analysis that intertwines Agamemnon's past crime with his present one. Thus, such recollection may have revived Clytemnestra's past distress and may stand as an inspiration as wells as a justification to flout Agamemnon, in her attempt to rise against the present misery he has inflicted upon one of her children (also refer to Daniels and Scully, 1992, p.205). Her choice is clear, she is ready to admit social loss by shedding attachment and loyalty to Agamemnon. Yet, she is still within the bounds of a conventional woman putting others, this time her daughter, before herself. In a way, she has surpassed her role as a wife to face the challenge of saving the child from the father's knife (cf. Hall, 1990, p.22). She attempts to shirk the authority of the husband but is still subordinate to male (Achilles') leadership. Accordingly, instead of simply communicating her distress and grief and succumb to a passive lament, her vulnerable circumstance empowered by her negative sentiments has induced her to be assertive towards averting the potential physical loss. Such mental condition is explicit as she confronts Agamemnon and mercilessly exposes his scheme to kill his own child (IA lines 1115 1143):

Clytemnestra: "Your daughter here, and mine, do you intend to kill her?" (IA line 1128)

Clytemnestra: “... I have heard all you planned to do to me.

Your very silence, all these mutterings of despair

Are your guilty confession...." (IA lines 1139-1141).

Clytemnestra in her rhetorical supplication to Agamemnon appeals to his inner self with reference to obligations expected from a father to his children, i. e. to ensure safety and care by giving them in marriage at the right time, and by increasing their wealth (Goldstein, 2018, p.144), and in which Agamemnon shall be a failure in the case of Iphigenia, unless he relinquishes from his scheme. She also refers to the impact of the scheme to kill Iphigenia on the reception that awaits Agamemnon at home in Argos. Despite the emotional vigour and dynamism of the arguments Clytemnestra failed to divert the mind of Agamemnon from sacrificing Iphigenia. This could be largely due to her inability to read the mind of Agamemnon, a replica of a perplexed human mind. Later, when the circumstances prevented Achilles from rising against Agamemnon and other Greeks Clytemnestra is seriously depressed and distressed, and when Iphigenia decides to accept her doom, she yields to mourn silently: 'Iph: Mother why are your eyes flowing with tears?' She finally accepts the crisis, though her distress continues to the end as can be discerned from her very last lines (IA lines 1616-1619), perhaps now to a bearable extent. ${ }^{12}$

${ }^{11}$ Pl. Meno, 71e-2a: 'A good housewife careful with her stores and obedient to her husband.'

${ }^{12}$ Accordingly, Clytemnestra too has displayed all stages of grief as explained by E. Kübler-Ross. See above, note 8. 


\section{Iphigeneia}

Iphigenia, a young affectionate maiden at the verge of her marriage, is the most appealing revolutionary character Euripides created for this play. Her parasitical and symbiotic relationship with her parents that has led to dependency is illustrated partly by her being chaperoned by the mother, Clytemnestra, to the Greek camp at Aulis, and partly by the extreme care the mother takes to secure Iphigenia's safety at the slightest possible physical risk, as she appears on stage:

"Girls help her to descend (from the chariot), give her your arms, now, hold her" (IA lines 604-605).

Also, her affectionate and naïve conversation with her father as she first met him in Aulis adds to such associations she had with her parents. Such scenes accelerate the tension and grief in the minds of the audience as they weigh it with the impending sacrifice (death) to which Agamemnon has driven his daughter. Confirming her dependence, Iphigenia follows her mother's instructions to beseech her father in the most appealing manner enlivening most delicate memories and moments of family attachments in the view of evading her tragic end (IA lines 1212-1252). The scene would make modern readers perceive Iphigenia as a child subjected to traumatic experience by her abusive father. Generally speaking, the scene exhibits how children become victims of war (Kaminer, and Eagle, 2010, pp. 122-145). Instead of presenting an abused or victimized child weeping relentlessly with her mother over her inevitable doom, Euripides presents Iphigenia with daring masculine traits such as autonomous disposition and rational thinking. ${ }^{13}$ The failure of Clytemnestra, Menelaus and Iphigenia to persuade Agamemnon was their inability to understand his complex or subtle internal psychological condition and personality or their incapacity to direct his consciousness to the course of action they were trying to influence (a study of Admetus and Phaedra in Conacher, 1981, pp.5-10). Such understanding of human mind partly depends on clear communication of emotions and underlying thoughts. Yet, it is no easy task to understand Agamemnon's mind as his internal values are at constant clash with those of the external values, which could perhaps be a clever Euripidean machination to bring Iphigenia to limelight. However, in many other Euripidean plays, such as in Alcestis, too the communication of grief and stress have at least facilitated the receipt of emotional support to overcome such negative sentiments.

However, Iphigenia is presented with the most unusual (though usual in terms of Euripidean standards) feminine behaviour exhibiting decision-making skills based on mature reflection (Bacalexi, 2010, p. 65) opting for autonomous disposition when all expectations of salvage lapsed. She claimed to have made the decision through careful observation and analysis of the circumstances:

"Mother, I have thought this over; I know now what I must do

I am resolved to die. Above all things, I want to act nobly

And renounce all cowardly feelings. Mother look at this with me,

And you'll see I am right. The power of Hellas now looks to me;

All lies in my hand..." (IA lines 1374-1378)

Accordingly, she brings the spot light and entire responsibility of saving Hellas (Greece) on her. Thus, she does not resort to retire passively to mourn silently over her doom. Instead, she has cultivated and strengthened new values and beliefs. This shift of character has resulted as she aligned her values with objective conditions of life and this process reaches climax when she advances through increased faith in herself (Hall, 1990, p.20). Increased faith has imparted a state of transcendence in Iphigenia. It also has influenced her positively to shun her dependence on others while enabling her to see the purpose of her life in the light of the broadest and deepest concerns while defining herself more powerfully as her values surpass her feminine sphere:

13 The most unexpected individual to possess such bold qualities in the eyes of Classical Athenian audience. 
"And indeed, I have no right to cling to life so passionately, Since it was for Greece you gave me birth, not for yourself alone." (IA lines 1384-1385)

"Shall my one life now prove the obstacle to their resolve?

Is this fair and just?..." (IA lines 1389-1390).

She stands firm accepting her lot and by doing so she casts away all negative emotional and psychological conditions. Awkward circumstances created by the male community (Greek generals and the army) appear to have progressively strengthened the mind of the naïve girl to break away from the integral part of human conditions dependency (also Hall, 1990, pp. 18, 20). With a similar determination she has shirked male authority and leadership by volunteering to offer her life for the land and its people. What shocked the Athenian audience would have been her attitude to shun male authority since self-sacrifice (arising from selflessness) of a woman was perceived by both genders alike as an ideal feminine virtue (Also Hall, 1990, p.100). It was her noble and objective attitude of patriotism along with submissiveness to divine power that has garnished her self-sacrifice, which otherwise would have considered slight. Iphigenia has also articulated her wish to conform to divine powers by humbly acknowledging their superiority.

"And if Artemis has laid a claim

On my body, who am I, a mortal, to oppose god?

This I cannot do. To Hellas, then, I dedicate myself." (IA lines 1396-1398).

One may argue in this context that the patriotic spirit and predisposition to Greek course engulfed in the panhellenic vision expressed by Iphigenia was due to paternal influence (Bacalexi, 2010, pp. 64-67. Also, Wilkins, 1988, p.12-13). But I would perceive that, presenting the most unexpected individual (a tender girl) with strong patriotic instinct is none other than a Euripidean machination to inculcate such instincts in the minds of the Athenians and their allies, when it is most needed. ${ }^{14}$

The autonomy she acquired has helped her to minimize the negative binding effects of dependency (also Hall, pp. $22,31,100,138)$ expressed through her words to Achilles. The words echo a sense of autonomy:

"So, Achilles don't either die for me or kill anyone else

But go, and leave me to save Hellas if I can." (IA lines 1420-1421).

She controls the situation (Bacalexi, 2010, p. 58), her assertiveness and the instructions to the others ${ }^{15}$ are very clear, just as her bold decision to convert her painful death to a noble memorable and a glorious sacrifice. She has profited from the situation by turning the moment as a device to immortalize her name by volunteering to sacrifice herself on behalf of Greece, and its people. Thus, she has traded something mediocre (her mortal self) for a better gain - the immortality of her name (Bacalexi, 2010, p. 52 and 55-57). Her self-sacrifice invoked by (Hall, 1990, p.138) altruism has lifted her status beyond household sphere and has assimilated it with the position of a warrior who die in battle for the country. The most notable fact is that Iphigenia's transcendence and resultant altruism has nurtured thoughts of compassion towards Achilles, (who failed to save her: IA lines 1371-1373) and Agamemnon (who schemed to kill her) while enhancing her capacity to endure her imminent death. She even bids her mother to share the compassion she feels for the father perhaps to reconcile her parents (IA lines 1369, 1455). As noted above, Iphigenia claimed to have released her grip of life, which has facilitated her to care for others creating harmonious relationships with them and persuading others to follow suit: "Do not hate Agamemnon. He

${ }^{14}$ During the last phase of the Peloponnesian War. Here we must remember that the Greeks perceived poet/ dramatist (poieth/j- poietej) as a teacher providing advice in times of need, which is the message transmitted through the poetic contest in Aristophanes' Wasps. Also see above note 7.

15 Iphigenia's instructions to Achilles (IA lines 1420-1421), to her mother Clytemnestra (IA lines 1433-1461, 1467 ) and to the Chorus of the women of Calchis (IA lines 1468-1499). 
is mine, and yours" (IA line 1453). Such perceptions are incurred from being emotionally invested with transcendental values, and by concentrating on her own values, thoughts and feelings, she dismisses others (even those who tried to kill her) as threats (Hall, 1990, p.138; also, Whitman, 1974, p.145). Such developments in the emotional spheres of one self could be interpreted as the final stage in the management of grief and stress. She herself was successful in the process of overcoming her distress but also attempts to help others to manage theirs as everyone's saviour (Whitman, 1974, pp. 138-139). In a way Iphigenia has found a resolution to her grief studded problem by accepting her death, which is also an acceptance of detachment from every bond. Her bid to abandon conventional practices of mourning and setting up of a tomb for her upon her death, and her renunciation to send messages to living siblings (IA lines 1437, 1441, 1447) also refer to her decision to shed all attachments which will redeem her from all distress and grief.

The wise despises human affairs as of little value in the process of alleviating distress. Iphigenia, a noble girl, may have acquired such perceptions through her religious values which projected gods and their affairs far superior to humans and of their affairs. Iphigenia's natural aptitude may have earned her this perception even though she was not destined to receive an excellent education just as any other Athenian woman of her calibre in the fifth century BC. According to Galen, people with best natural aptitude and finest moral education require training throughout life (Tielman, 2019, p. 202). Since the audience of Greek tragedies were males who could afford money and time to entertain themselves through such spectacles, one of the intentions of the tragic poet could be to provide a visual training to his audiences to overcome distress in order to experience a cathartic effect (purgation/ purification of excess emotions as pity and fear). This reminds us of the emotional training the stoics and later philosophers proposed in order to relieve one from distress, and it was to make one imagine one's worst fears come true. ${ }^{16}$ Though this concept is post Euripidean, belonging to Roman era, most of the Greek tragedies emanated the most aghast and horrific fear. For instance, impending death of Alcestis (in that name-play) and the death of Iphigenia (in the play of our concern in this study) and the enslavement of the royal ladies depicted in Andromache, and Trojan women are such worst fears the Greeks could ever imagine. Accordingly, what stoics and later philosophers expounded towards Roman era was already practised by Classical Athenian tragedians as a means of training their audiences to communicate, manage and to overcome their grief and stress.

Moreover, in Iphigenia in Aulis, the tension rises gradually when negative emotions such as grief and stress were communicated by the respective characters. The tension drops temporarily when Iphigenia expressed her decision to die for Greece. It resumes to some extent as Achilles extends his help until the last minute of Iphigenia's life (IA lines 1425-1432). Thus, the awe-struck audience may have observed Iphigenia's every move with a hanging suspicion and may have left them breathless as the messenger reported the incident confirming the heroic stature of the maiden as she faced death, and her miraculous disappearance bringing relief to Agamemnon, to the chorus of Calchian women and also to the audience. Accordingly, the communication of grief and stress which is closely connected with pity and fear has led to catharsis of same emotions (Mierow, 1953, p.247) by showing how to manage, if not to alleviate them. The initial step was communication of such sentiments. Euripidean innovation was to use the most supposedly meek and unexpected character to behave bold, relieving all characters including herself and even the audience from negative emotions. Such a procedure could have been used to indicate that all humans, irrespective of gender and age, are capable of acting bold, a lesson Euripides may have sought to teach contemporary Athenian audience, in their decisive moment during the Peloponnesian war as a part of war time propaganda.

16 This practice was known as 'dwelling in advance' (proendhmei=n -proendemein) Stated in Cicero's Tusc. 3.28-31. 


\section{Conclusion}

In conclusion, the present study has shown that Euripides' Iphigenia at Aulis was not a mere presentation of character, themes and motives but also a modelling dynamic or stage rehearsal of communicating their negative psychological conditions such as grief and stress with a view to manage, if not alleviate, these negative emotions while causing the same impact on the audience. Such conception could also be true with regard to many of Euripidean tragedies. Moreover, each character in the play concerned, revealed that they communicated their grief and stress in an attempt to manage these sentiments in a way peculiar to themselves such as from bearing a positive attitude, accepting the situation to being assertive instead of being aggressive. Last but not least, it would be interesting to extend the focus of this study to explore the psychology of female characters in all ancient Greek tragedies.

\section{Acknowledgements}

Hereby, I would like to express my gratitude to the University of Peradeniya for granting me sabbatical leave in 2018 and also to the Dept of Classics at the University of Canterbury, New Zealand, for welcoming me as visiting scholar, as it was during my stay at Canterbury, I collected the initial data for this study.

\section{References}

\section{Printed sources}

Thomas, L. (1987). Friendship. Synthesis, 72, Kurt Baier Festschrift, (2), 217-218.

Baron-Cohen, S. (1995). Mind blindness. An Essay on Autism and Theory of Mind. Cambridge, University Press.

Dunbar, R. (2000). On the origins of the human mind. in P. Carruthers and A. Chamberlain (eds) Evolution and the human mind. Modularity, language and Meta-Cognition, Cambridge, University Press.

Hall, C. M. (1990). Women and identity: value choices in a changing world, New York, Hemisphere Press.

Whitman, C. H. (1974). Euripides and full circle of myth. Cambridge, University Press.

Zunts, G. P. (1955). The political plays of Euripides. Manchester, University Press.

\section{Electronic sources}

Allard, J-N, Montlahuc, P. and Rothstein, M. (2018). The gendered construction of emotions in the Greek and Roman worlds. Clio, Women, gender, history (47) Gender and the emotions, 23-44.

Retrieved from URL: http:// www.jstore.org/stable/10.2307/26934335. 02 Nov. 2020.

Arrowsmith, W. (1963). Greek theatre of ideas. Arion: A journal of Humanities and Classics, 2 (3), 32-56.

Retrieved from URL: http:// www.jstore.org/stable/20162850. 05 Feb 2020

Bacalexi, D. (2016). Personal, paternal, patriotic: the threefold sacrifice of Iphigenia in Euripides' Iphigenia in Aulis. Humanitas, Imprensa da Universidade de Combra, 68, 51-76.

Retrieved from URL: 10.14195/2183-1718_68_3. halshs-01640103. 02 Nov 2020.

Briassoulis, H. (2019). The Catharsis of the commons. International Journal of the Commons, 13 (2), 1092-1111. Retrieved from URL: http:// www.jstore.org/stable/26819589. 29 Jan 2020.

Budelmann, F., and Easterling, P. (2010 Oct). Reading minds in Greek tragedy. Greece \& Rome, second series, 57 (2), 289-303. Retrieved from URL: http://www.jstore.org/stable/40929480. 27 May 2016.

Cavarnos, C. (1979 Jan-Feb). Art as a means of therapy according to Aristotle. The Classical Outlook, 56 (3), 56 59. Retrieved from URL: http://www.jstore.org/stable/43934008. 29 Jan 2020.

Conacher, D. J. (1981). Rhetoric and relevance in Euripidean drama. The American Journal of Philology, 102 (1), 3-25. Retrieved from URL: http://www.jstore.org/stable/294148. 27 May 2016.

Daniels, C. B., and Scully, S. (1992). Pity fear and Catharsis in Aristotle's Poetics. Nous, 26, 204-217. Retrieved from URL: http://www.jstore.org/stable/2215735. 29 Jan 2020. 
Ferguson, J. (1968). Iphigeneia at Aulis. Transactions and Proceedings of the American Philological Association, 99, 157-163. Retrieved from URL: http:// www.jstore.org/stable/2935837. 20 Jan 2016.

Gamliel, T. (2014). Therapeutic aspects of "Traditional” wailing performance. Journal of Ritual Studies, 28 (1), 45-63. Retrieved from URL: http:// www.jstore.org/stable/44368886. 23 Jan 2020.

Goldstein, R. D. (2018). Parental grief, in J. R. Duncan (ed) SIDS Sudden infant and early childhood death, the past the present and the future, Adelaid, University of Adelaid Press.

Retrieved from URL: http:// www.jstore.org/stable/10.20851/j.ctv2n7f0v.12. 23 Jan 2020.

Kaminer, D., and Eagle, G. (2010). Trauma and children, in D. Kaminer \& G. Eagle (eds)

Traumatic stress in South Africa, Johannesburg, Wits University Press. Retrieved from URL: http:// www.jstore.org/stable/10.18772/22010105096.9. 23 Jan 2020.

Kim On Chong-Gossard, J. H. (2003 Autumn-Winter). Song and the solitary self: Euripidean women who resist comfort. Phonix, 57 (3 / 4), 209-231. Retrieved from URL: http:// www.jstore.org/stable/3648514. 20 Jan 2016.

Konstan, D. (1999 Spring). The tragic emotions. Comparative Drama, 33 (1), Tragedy's insights: Identity, Polity, theodicy, 1-21. Retrieved from URL: http:// www.jstore.org/stable/41153957. 29 Jan 2020.

MacCandless, J. B. (1978). Dealing creatively with suffering -the living death. The journal of Religion and Health, 17 (1), 19-30. Retrieved from URL: http:// www.jstore.org/stable/27505428. 23 Jan 2020.

Mierow, H. E. (1953 Apr). The amazing modernity of Euripides. The Classical Journal, 48 (7), 247-252. Retrieved from URL: http:// www.jstore.org/stable/3293765. 05 Feb 2020.

Pritchard, D. M. (2014 Oct). The position of Attic women in democratic Athens. Greece and Rome, second series, 61 (2), 174-193. Retrieved from URL: http:// www.jstore.org/stable/43297497. 02 Nov 2020.

Sim, J., L. Machin and Bartlam, B. (2014 May). Identifying vulnerability in grief: psychometric properties of the adult attitude to grief scale. Quality of Life Research, 23 (4), 1211-1220. Retrieved from URL: http:// www.jstore.org/stable/24726419. 23 Jan 2020.

Tielemann, T. (2019). Wisdom and emotion: Galen's philosophical position in avoiding distress. in C. Petit (ed) Galen's treatise Peril )Alupi/aj (De indolentia) in context, A tale of resilience, Leiden,, Brill. Retrieved from URL: http://www.jstore.org/stable/10.1163/j.ctvrxk2wj.11. 23 Jan 2020.

Wilkins, J. (1988). Voluntary self-sacrifice in Euripides. The Classical Review, new series, 38 (1), 12-13. Retrieved from URL: http://www.jstore.org/stable/3065895. 27 May 2016

Woodruff, P. (2016 Jan). Sharing emotions through theatre: the Greek way. Philosophy East and West, 66 (1), Special issue: Theatre and character cultivation in three great philosophical cultures, 146-151. Retrieved from URL: http://www.jstore.org/stable/43831288. 23 Jan 2020. 